\title{
AN ANALYSIS OF PERSONALITY TRAITS OF INDONESIAN START-UP ENTREPRENEURS BASED ON SOCIAL MEDIA FOOTPRINT
}

\author{
Banguning Asgha*)1, Dang Arif Hartono*), Metta Suryatie Halim*), Katherin Wijaya*), \\ Elaine Ngan*), and Claudy Marciani Surya*) \\ *) Entrepreneurship Study Program, Universitas Agung Podomoro \\ Jl. Let. Jend. S. Parman Kav. 28, Podomoro City, Jakarta Barat 11470, Indonesia
}

\begin{abstract}
The objective of this research was to analyze the personality traits of successful Indonesian start-up entrepreneurs whose businesses were in the top 200 based on startupranking.com. Using IBM Watson Personality Insights, the Big Five personality traits from 27 samples were measured. The Big Five personality traits include openness, conscientiousness, extraversion, agreeableness, and neuroticism. The data were analyzed using descriptive statistics and mean comparison. Mann-Whitney U test was used to determine the difference in personalities between genders, while the Spearman test was utilized to identify the correlation between education level and personalities. The results revealed that Indonesian start-up entrepreneurs tended to be more open, more conscientious, moderate in extraversion, less agreeable, and more neurotic $(\mathrm{O}+, \mathrm{C}+$, E, A-, N+). There was no personality difference in different genders and no correlation between education level and personality traits either. The results of this study should serve as a point of departure for future studies on start-up entrepreneurs' personality traits in Indonesia. Additionally, future studies are suggested to employ a larger number of samples from different countries.
\end{abstract}

Keywords: angel investors, big five personality traits, Indonesian entrepreneurs, social media analysis, start-up

\begin{abstract}
Abstrak: Tujuan dari penelitian ini adalah untuk mengetahui kriteria kepribadian pengusaha bisnis start-up sukses Indonesia yang bisnisnya berada pada ranking 200 besar berdasarkan peringkat start-upranking.com. Dengan menggunakan IBM Watson Personality Insights, kriteria kepribadian the Big Five dari 27 orang sampel diukur. Kriteria kepribadian the Big Five meliputi keterbukaan, ketelitian, ekstraversi, kesetujuan, dan neurotisme. Data dianalisis menggunakan statistik deskriptif dan perbandingan rata-rata. Uji Mann-Whitney U dilakukan untuk menentukan perbedaan pada jenis kelamin, sedangkan uji Spearman digunakan untuk mengidentifikasi korelasi antara tingkat pendidikan dengan karakter kepribadian. Hasil penelitian menunjukkan bahwa pengusaha bisnis start-up Indonesia cenderung lebih terbuka, lebih cermat atau berhati-hati, memiliki tingkat ekstraversi yang sedang, memiliki tingkat kesetujuan yang lebih rendah, dan mempunyai nilai neurotisme yang lebih tinggi $(\mathrm{O}+, \mathrm{C}+, \mathrm{E}, \mathrm{A}-$, $\mathrm{N}+$ ). Tidak ditemukan adanya perbedaan kepribadian antar jenis kelamin dan tidak ada korelasi yang signifikan antara tingkat pendidikan dan karakter kepribadian. Hasil penelitian ini dapat menjadi rujukan awal bagi studi mendatang mengenai karakter kepribadian pengusaha start-up Indonesia. Selain itu, studi mendatang disarankan untuk menggunakan sampel yang lebih besar dari beragam negara.
\end{abstract}

Kata kunci: analisis media sosial, karakter kepribadian big five, penanam modal, pengusaha Indonesia, start-up

\footnotetext{
${ }^{1}$ Corresponding author:

Email: banguning.asgha@podomorouniversity.ac.id
} 


\section{INTRODUCTION}

The development of technology has played a positive role in the rise of entrepreneurship. It can be seen from the emergence of numerous start-up businesses in several countries. Startupranking.com (2019) indicated that Indonesia is the fifth country with the highest number of start-up businesses (2,111 start-ups)(Figure $1)$.

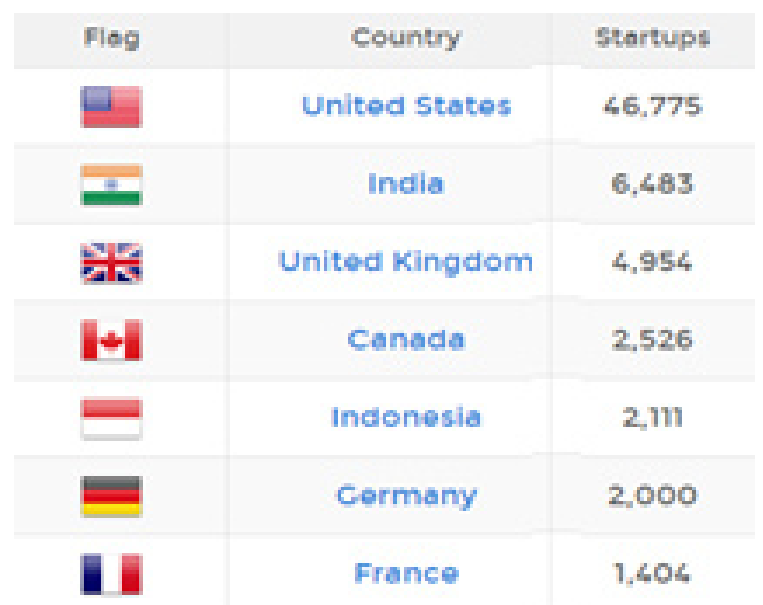

Figure 1. Countries with the highest number of start-up companies

The growth of start-up businesses leads to the need for capital and opens the opportunity for investors to inject their money into promising businesses. Following the growth of Indonesian start-up businesses, the amount of money invested by venture capitals increased significantly, reaching 200 million USD in 2015 (Widyasthana et al. 2017). It is predicted that the number will continually rise. Consequently, the number of venture capital operating in Indonesia is also increasing with different levels and schemes of funding (Widyasthana et al. 2017). In addition to capitals from angel investors or venture capitals, start-up businesses could also look into the possibility of securing capital from banks. Before lending money to entrepreneurs, banks will undergo a feasibility study, and the common method used to assess a prospective debtor, either personal or institutional, is the $5 \mathrm{C}$ principles (character, capacity, capital, collateral, and condition) (Kasmir, 2012).

The assessment to determine whether or not prospective debtors can be lent some money involves a series of investigations on their reputation and track record. The techniques commonly applied in this process include interviewing prospective debtors, examining the debtors' credit score, checking on the spot (COS), trade checking, and checking in the club (Kasmir, 2012). COS involves visiting the debtors' residence and or valuing their collateral. Trade checking includes tracking their business records with their business partners or suppliers. Checking in the club involves interviewing the people in their business and personal networks.

Although it has become a common practice, the objectivity of the current technique for assessing prospective debtors' character is questionable. This technique relies heavily on the use of interviews to find information about the prospective debtors from their colleagues, business partners, or neighbors. If not appropriately implemented, interviews might produce biased responses. According to Widyasthana et al. (2017), a more objective method is needed to assess the character of prospective debtors so that investors or venture capitals can make the right decision to whom the money should be lent. Therefore, there is a clear need for a character assessment tool that would produce a more objective result.

One of the most commonly used tools to analyze one's character is the five-factor model of personality traits or widely known as the Big Five. While the pioneering work on the Big Five started in the early 1960s (Tupes and Christal, 1961; Norman, 1963), the five-factor model as known today might be best attributed to Costa and McCrae $(1990,1992)$ and McCrae and Costa (1987, 1991) who contributed to the revision and reformulation of the previous models. The Big Five examines people's personalities based on the language they use and then describes them in five dimensions: Openness to experience, Conscientiousness, Extraversion, Agreeableness, and Neuroticism (OCEAN). Openness to experience is a measure of one's response to new ideas, imagination, and artistic and natural appreciation. Conscientiousness appraises one's self-control and discipline. One's engagement with the external world is gauged by extraversion. Meanwhile, one's tendency to value harmony and get along with others is reflected through agreeableness. Finally, neuroticism signals one's emotional stability (McCrae and Costa, 1991).

In the literature of personality research, the Big Five is considered as a model that has better explanatory power (McCrae and Costa, 1991). It has also been utilized in studies across different areas of research, such as psychology (Costa and McRae, 1990), safety driving (Arthur and Graziano, 1996), marketing 
(Na and Marshall, 1999), employees' performance (Rothmann and Coetzer, 2003), personality and online behavior (Ryan and Xenos, 2011), entrepreneurial personality (Leutner et al. 2014), etc. Furthermore, the Big Five personality model has recently been used in understanding personality based on social media postings. Previous studies incorporating the Big Five model investigated diverse types of subjects, starting from entrepreneurs and managers (Obschonka et al. 2017), celebrities (Dutta et al. 2017), to political extremists (Alizadeh et al. 2017).

Previous studies (Alizadeh et al. 2017; Dutta et al. 2017; Obschonka et al. 2017) revealed that one's personality could be understood by analyzing the language he/she uses in his/her postings on social media using an online computer program called IBM Watson Personality Insights. The program analyzes one's personality, including characters, way of thinking, and possible preferences. IBM Watson Personality Insights has been used in understanding personality traits based on online postings in various contexts (Dutta et al. 2017; Hu et al. 2016; Mostafa et al. 2016; Obschonka et al. 2017; Thies et al. 2016). Relying on the analysis of one's language, this personality assessment technique is arguably more objective than the current, widely used debtor's character assessment method that merely depends on interviews.

This study investigated the personality traits of successful Indonesian start-up entrepreneurs. The focus of this study was to understand the character of successful entrepreneurs by analyzing their personality traits as reflected by their postings on their social media accounts.

\section{METHODS}

The population in this study was start-up business owners who were considered successful. Successful start-up business owners in this context were defined as those who founded and run their start-up business and get into the top 200 startupranking.com. This justification was deemed fit as the start-ups in the top 200 included well-known Indonesian start-up businesses such as Tokopedia, Bukalapak, Blibli, Traveloka, Pegipegi, Berrybenka, Nusatrip, Ruangguru, and other popular start-up companies.
According to Arikunto (2010), in defining the number of samples, researchers must pay attention to the population size. If the population is less than 100 individuals, all of them should be included as the samples. If the population size is bigger than 100 people, the samples could be $10-25 \%$ of the population. Therefore, in this study, researchers collected data from 27 successful start-up entrepreneurs because the number was considered representative of the 200 people in the population. In determining the sample, researchers used judgmental sampling. It is deemed to be appropriate because, in this study, the researchers wanted to see a similar set of characters from a group of similar individuals, namely the successful startup entrepreneurs. Judgmental sampling is the best approach to obtain data from one specific sample group (Cooper and Schindler, 2014).

The samples in this study were chosen based on several criteria, including: Recorded as the founders of an Indonesian start-up business that was ranked in the top 200 in startupranking.com; Having a social media account which postings could be accessed publicly; Having some postings on social media accounts written in English and with the number of accumulated words from the overall postings reached at least 600 words. Individuals who did not meet these criteria were not included as the samples of this study.

The instruments used in this study were as follows: 1) Research assistants (recruited to collect data (posts) from social media accounts of successful Indonesian start-up entrepreneurs); 2) Researchers (compiled and validated the data collected by the research assistants. To ensure that IBM Watson Personality Insights could process the data, the researchers made some necessary adjustments. For example, fixing incorrect punctuations and misspellings, changing internet colloquial terms or abbreviations to written words, making sure the number of words reaches the minimum requirement of 600 words in IBM Watson Personality Insights, etc); 3) IBM Watson Personality Insights (an online computer program that can analyze individual characters, thinking styles, and personal preferences based on personal writings. It has been validated and used by researchers to analyze the characters or personalities based on written language produced in a variety of context (Alizadeh et al. 2017; Dutta et al. 2017; Hu et al. 2016; Mostafa et al. 2016; Obschonka et al. 2017; Thies et al. 2016)). 
The data were collected through the following procedure: The research assistants gathered all data of social media postings from the top 200 Indonesian entrepreneurs and submitted them to the researchers; The researchers validated all the data including checking the number of words, mistyping corrections, etc.; Validated data were analyzed using IBM Personality Insights to get scores indicating the Big Five personality traits from the samples; Data on the personality traits were analyzed using descriptive statistics and mean-comparisons. Mann-Whitney U test and Spearman test were used to analyze the relationship of demographic factors and personality traits.

The data were calculated using IBM SPSS version 20 to find the descriptive statistics and frequency distribution. Descriptive statistics were used to summarize processed data without making an inferential judgment (Shao, 2002), while frequency distribution was used to analyze the number of certain values displayed in graphs, charts, or diagrams (Aaker et al. 2006). Mann-Whitney U test was used to determine the relationship between genders and personality traits, while the Spearman correlation test was carried out to identify the correlation between education level and personality traits of start-up founders.

\section{RESULTS}

\section{Profile of Samples}

Of the total 200 Indonesian start-up entrepreneurs in the population, only 27 people met the criteria. The results showed that the average number of words per person obtained from the 27 samples was 1,008 words. The highest number of words was 1,996 , while the lowest number of words was 600 . This result was good, considering that the IBM Watson Personality Insights requires at least 600 words to obtain statistically significant analysis results. The descriptive statistics of samples are shown in Table 1.

Demographically, the samples were dominated by males, with 23 males and only 4 females. Two interpretations could explain this phenomenon. First, this could be an indication that there was still a gender imbalance in the start-up world. In their study on the number of male and female entrepreneurs in 43 countries, Pines et al. (2010) found that the number of female entrepreneurs was lower than the number of male entrepreneurs. Similarly, Hartono et al. (2018) also found in their study that the top 200 world start-ups were mostly founded and ran by males. The second interpretation that can also be taken from this finding is that gender could play a role in the type of business established by someone. Hechavarria and Ingram (2016) discovered that men tend to set up a business that is commercial (commercial entrepreneurship), and women tend to establish a business that is social (social entrepreneurship). Given that the majority of start-up businesses ranked in startupranking. com are commercial, then it is no surprise that the samples are mostly male entrepreneurs.

When it comes to the level of education, the majority of start-up entrepreneurs held an undergraduate degree, eight people owned a master's degree, and the remaining three people were college dropouts. It was difficult to obtain data on the age of start-up entrepreneurs with a simple internet search. In this study, the researchers only managed to find the age of 7 people out of 27 entrepreneurs taken as the sample.

Table 1. Descriptive statistics of samples

\begin{tabular}{lcccc}
\hline \multicolumn{1}{c}{ Categories } & Total $(\mathrm{n})$ & Average value & Max. value & Min. value \\
\hline Number of words & 27 & 1,008 & 1,996 & 600 \\
Gender & 27 & & & \\
Male & 23 & & & \\
Female & 4 & & & \\
Age & 27 & & 45 & 27 \\
Known & 7 & 34.6 & - & - \\
Unknown & 20 & - & & \\
Education level & 27 & & & \\
Bachelor degree dropouts & 3 & & & \\
Bachelor degree & 14 & & & \\
Master degree & 8 & & & \\
Unknown & 2 & & & \\
\hline
\end{tabular}




\section{The Big Five Personality Traits}

The results presented in Figure 2 provide information about entrepreneurs' personality traits. By using a scale of 0 to 100 , the result revealed that generally, successful start-up founders scored high on neuroticism (75.32). It was relatively high on conscientiousness (67.97) and openness (65.13), moderate on extraversion (53.22), and low on agreeableness (38.03).

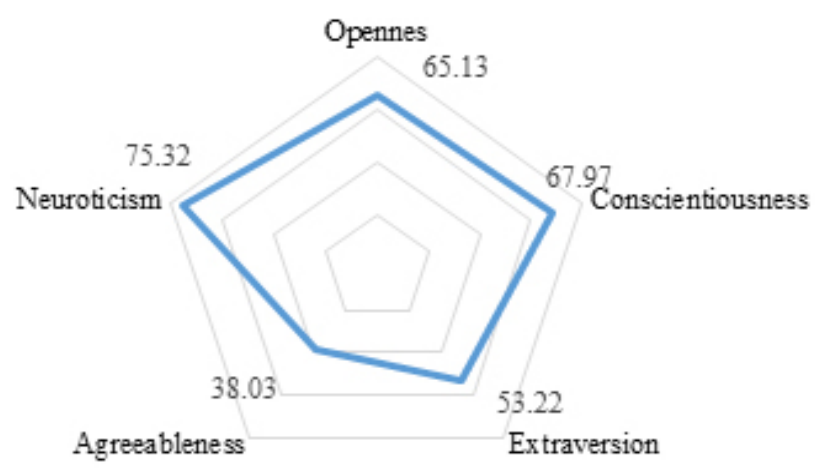

Figure 2. Average value of start-up founders' personality traits

The highest average score was on neuroticism (75.32). Neuroticism is an indicator of an individuals' level of emotional sensitivity to his environment (Costa and McCrae, 1992). Individuals with a high score on this trait tend to feel angry, anxious that something terrible will happen, sensitive to what other people think about them, as well as feel stressed. This finding indicated that successful start-up founders tended to feel under pressure, which might be caused by the risk they have to face in running their business.

Successful start-up founders had a relatively high level of conscientiousness (67.97). Conscientiousness reflects a person's tendency to think and act with consideration and caution (Costa and McCrae, 1992). Conscientiousness also demonstrates the degree of organization, commitment, hard work, and determination of a person to accomplish a goal (Zhao and Seibert, 2006). This result was in line with the findings from Zhao and Seibert (2006) in their metaanalysis of 23 studies on entrepreneurs' and managers' personality traits. They found that entrepreneurs had a higher score on conscientiousness because it might be needed in the post-launch phase when entrepreneurs were more focused on delivering their products or services. Lounsbury et al. (2009) also noted that business jobs and professional careers require consciousnessrelated activities, such as setting goals and meeting expectations. In other words, this trait exemplifies that entrepreneurs are goal-oriented and highly committed individuals, and this is not surprising because the nature of their job demands them to be that way.

Openness is a factor that reflects an individual's level of willingness to experience or face a variety of new things (Costa and McCrae, 1992). People who score high on openness tend to be open to try new things and see routines as boring. They also show interest in art, beauty, and nature, can understand their feelings, be imaginative, be curious, and tend to oppose authority, habits, and old values. The result showed that successful start-up founders had a moderate level of openness (65.13). It indicated that desiring to try new experiences, interested in arts and beauty, and having imaginative thoughts were all the traits of successful entrepreneurs. It made sense because start-up founders need imagination and creative ideas to set up their business. This result also corroborated Kerr et al. (2017), who argued that entrepreneurs tended to be more open and interested in continuous environmental change and new challenges.

On average, the successful start-up founders scored moderately on extraversion (53.22). Extraversion is a measure of an individual's tendency to seek stimulation or encouragement by associating with others. A high score on this factor implies a tendency to feel happy and comfortable getting along with people and be assertive and directive. Moderate value on extraversion might imply that start-up founders tend to be quite balanced in terms of socializing and doing their business. Further studies are needed to validate this notion because the literature on the significance of this personality trait in entrepreneurs is still limited.

It was found that agreeableness is a personality trait with the lowest average score (38.03). The low level of agreeableness in this study corroborated the finding in a previous study by Ciavarella et al. (2004). This trait explains the tendency of an individual to be compassionate and cooperative with others. People with a high level of agreeableness tend to be empathetic, helpful, and conflict-avoidant. According to Zhao and Seibert (2006), this happens because entrepreneurs need a very high self-confidence to take risks in running their business. Kerr et al. (2017) added that, compared to managers, entrepreneurs tend not to worry if they do not please someone because they usually become the CEOs of the company they founded. It is different from managers who must please their boss. This finding 
corroborated the finding from the study conducted by Antoncic et al. (2015) in Slovenia. They found that those who scored high on agreeableness would be less likely to be entrepreneurs and vice versa. It pointed to two possibilities, namely the sympathetic nature and kindness, as well as the nature of start-ups that lack resources. Sympathetic character and kindness might hamper the start-up's decision-making process and business activities. Meanwhile, the nature of start-ups that is lack in resources forces entrepreneurs to focus more on completing their tasks and leave little room for adjusting to external parties (employees, government regulations, etc.).

This study generally found that successful start-up founders tended to be more open and more prudent. They had moderate extraversion, lower agreeableness, and were more likely to be neurotic $(\mathrm{O}+, \mathrm{C}+, \mathrm{E}, \mathrm{A}-$, $\mathrm{N}+$ ). These results were almost similar to the findings in Zhao and Seibert (2006), who examined the differences in personality traits of entrepreneurs and managers. Their findings suggested that compared to managers, entrepreneurs tended to be more open to new experiences and more thorough, while the extraversion level was not significantly different from managers. Additionally, their agreeableness and neuroticism were lower than that of the managers. Therefore, in their study, they found that the composition of entrepreneurs' personality traits was $\mathrm{O}+, \mathrm{C}+, \mathrm{E}, \mathrm{A}-, \mathrm{N}-$.

\section{Correlation between Demographic Factors and Personality Traits}

Before deciding what statistical procedure to use, the Shapiro-Wilk test was run to determine whether or not the data were normally distributed. The result showed that the data on openness, extraversion, and neuroticism were normally distributed (sig. $>0.05$ ). Meanwhile, the data on conscientiousness and agreeableness were not normally distributed. Given that not all the data were normally distributed and the number of samples was limited, the researchers decided to use the non-parametric approach to analyze the data.

The Mann-Whitney U test is a non-parametric test which is used to determine the median difference between two free median groups if the dependent variables are using ordinal, interval, or ratio scale. In this study, the MannWhitney $U$ test was used to determine whether there was a significant difference in genders. Meanwhile, the Spearman correlation coefficient was used to determine the relationship between educational level and personality traits. According to Schober et al. (2018), the Spearman correlation coefficient is used for continuous data that is not normally distributed, ordinal data, or data with outliers relevant to measuring monotonic association. The Spearman coefficient has a range from -1 to 1 , where 0 indicates no linear relationship or monotonic association. Besides looking at the correlation between variables, this study also compared the mean difference of personality traits between genders and education levels. The study did not analyze the relationship between age and personality traits because the data on the age of the samples was minimal.

Figure 3 shows that, on average, females scored higher on all personality traits than males. However, the result of the Mann-Whitney $U$ test indicated that there was no significant difference between males' and females' personality traits ( $p$-value $\geq 0.05$ ). A limited sample of 27 individuals made this finding require further studies with a larger number of samples.

Figure 4 shows that in general the higher the education level, the higher the score on all components of personality traits, except on conscientiousness. However, further statistical analysis did not indicate a significant difference between the score of those with masters' degree, undergraduate degree, or even the college dropouts. This might have something to do with the small number of the samples. Further research with a larger number of samples is necessary to obtain a definitive answer on this issue.

\section{Managerial Implications}

This study shows that successful Indonesian start-up entrepreneurs have the following personality traits: $\mathrm{O}+$, $\mathrm{C}+, \mathrm{E}, \mathrm{A}-, \mathrm{N}+$. One notable implication from this study is that it can be used as a reference in identifying future leader candidates as research showed entrepreneurial traits in an executive are correlated to a venture's growth (Baum and Locke, 2004). In addition, human resource departments might want to provide training programs that would shape employees' personality to embody the desirable entrepreneurial personality traits. Finally, it is possible to assess one's character by analyzing his/her postings on social media using IBM Watson Personality Insights, so this tool might be utilized by angel investors, venture capitals, and banks to bolster the current method used to assess a prospective debtor's character that relies only on interviews. 


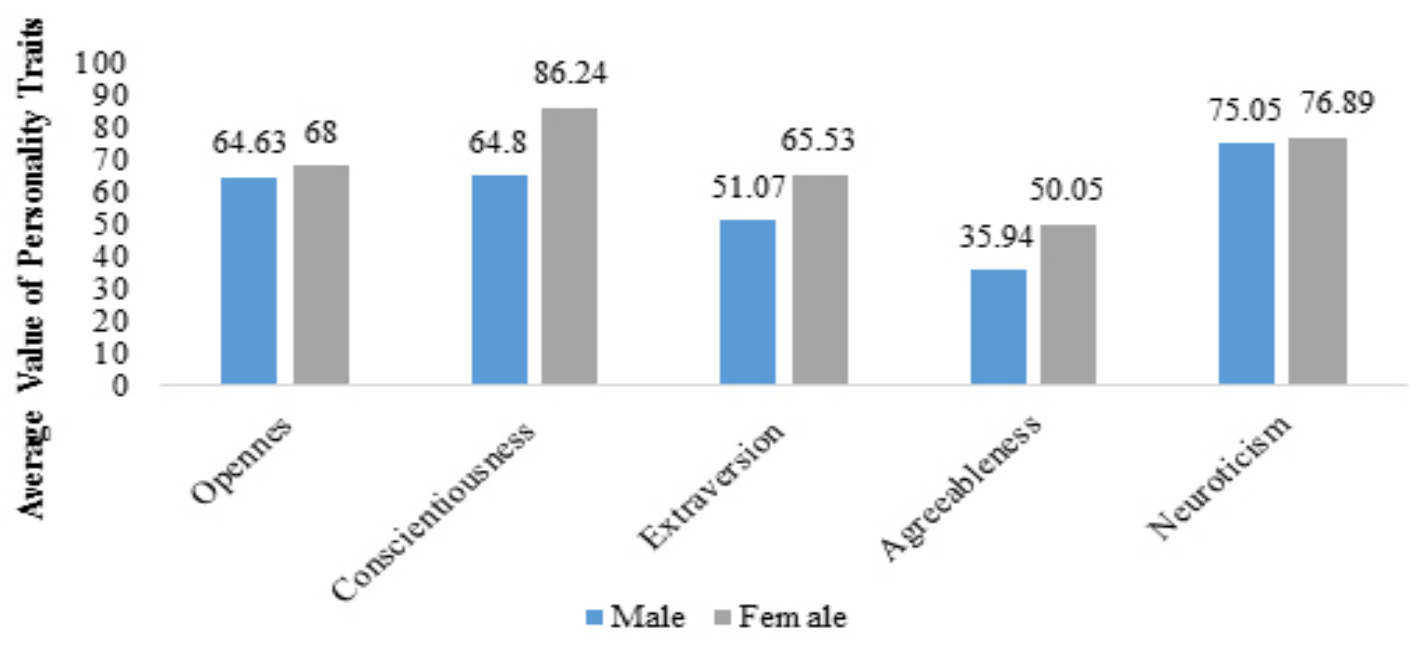

Figure 3. Average value comparison of personality traits based on gender

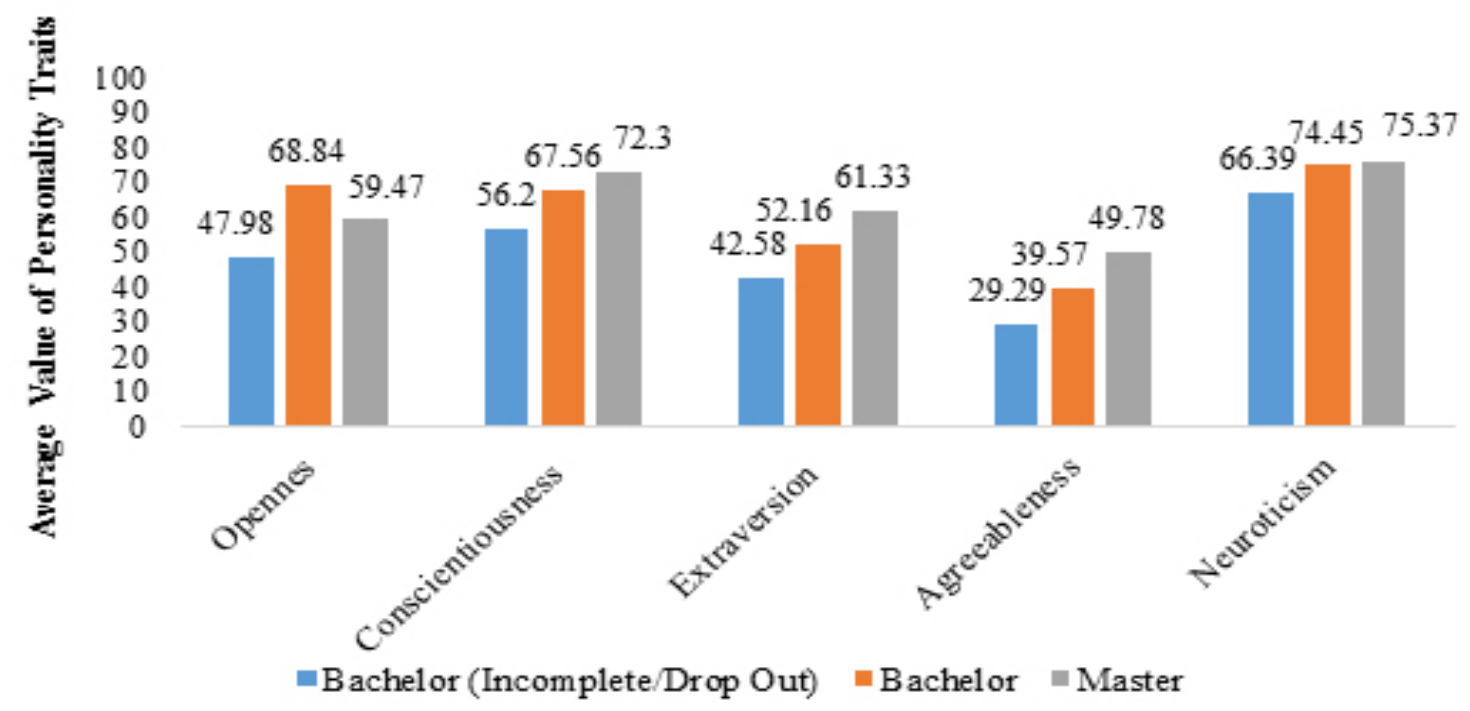

Figure 4. Average value comparison of personality traits based on education

\section{CONCLUSIONS AND RECOMMENDATIONS}

\section{Conclusions}

This study revealed that successful start-up founders tended to be open to a new experience or change. They also tended to think and act quite thoughtfully and cautiously. Besides, they had a moderate level of extraversion, a low level of agreement, and a high level of neuroticism $(\mathrm{O}+, \mathrm{C}+, \mathrm{E}, \mathrm{A}-, \mathrm{N}+)$. The results of this study also found that there were no significant differences in the personality traits of male and female start-up founders, and there was no significant correlation between education level and the five personality traits studied. One notable implication from this study is that it is possible to assess one's character by analyzing his/her postings on social media using IBM Watson Personality Insights. Therefore, this tool might be utilized to bolster the current method used to assess a prospective debtor's character that relies only on interviews.

\section{Recommendations}

One of the limitations of this study was the limited number of samples and the limited data on the samples' age. Therefore, it is recommended that further studies employ a larger pool of samples to obtain more convincing results and discuss additional issues that arise from their findings. Additionally, there is a need 
for similar studies to be carried out in several other countries, so it suggested that future studies to compare the personality traits of start-up founders in different countries. Thus, a more generalizable finding could be reached.

\section{ACKNOWLEDGMENTS}

We are thankful to the Ministry of Research, Technology, and Higher Education (Kemenristekdikti) for the research grant (Early Career Researcher Grant/ Hibah Penelitian Dosen Pemula) provided to us to complete this study.

\section{REFERENCES}

Aaker DA, Kumar V, Day GS. 2006. Marketing Research. 8th ed., Hoboken: Wiley.

Alizadeh A, Weber I, Cioffi-Revilla C, Fortunato S, Macy M. 2017. Psychological and Personality Profiles of Political Extremists. https://arxiv.org/ abs/1704.00119.[17 June 2019].

Antoncic B, Kregar TB, Singh G, DeNoble AF. 2015. The big five personality-entrepreneurship relationship: evidence from Slovenia. Journal of Small Business Management 53(3): 819-841. doi: $10.1111 /$ jsbm.12089

Arikunto S. 2010. Prosedur Penelitian: Suatu Pendekatan Praktik. (Edisi Revisi). Jakarta: Rineka Cipta

Arthur W, Graziano W. 1996. The five-factor model, conscientiousness, and driving accident involvement. Journal of Personality 64(3):593618.

Cooper DR, Schindler PS. 2014. Business Research Methods. 12th Ed. New York: McGraw-Hill Education

Costa PT, McCrae RR. 1990. Personality disorders and the five-factor model of personality. Journal of Personality Disorders 4(4): 362-371. http:// dx.doi.org/10.1521/pedi.1990.4.4.362

Costa PT, McCrae RR. 1992. Revised NEO Personality Inventory (NEO-PI-R) and NEO Five-Factor Inventory (NEO-FFI) professional manual. Odessa: Psychological Assessment Resources.

Dutta K, Singh VK, Chakraborty P, Sidhardhan SK, Krishna BS, Dash C. 2017. Analyzing big-five personality traits of Indian Celebrities Using online social media. Psychological Studies
62(2):113-124. https://doi.org/10.1007/s12646017-0408-8

Hartono DA, Asgha B, Halim MS, Oktobriando A, Ngan E, Liandi J. 2018. Analisis Karakter Pengusaha Start-up Dunia berdasarkan Rekam Jejak Digital di Sosial Media. Indonesia Journal of Entrepreneurship 4 (1): 96-107.

Hechavarria D, Ingram A. 2016. The entrepreneurial gender divide: hegemonic masculinity, emphasized femininity, and organizational forms. International Journal of Gender and Entrepreneurship 8(3): 1-39.

Hu T, Xiao H, Luo J, Nguyen TT. 2016. What the Language YouTweetSaysAboutYourOccupation. Paper presented at the Tenth International AAAI Conference on Web and Social Media (ICWSM 2016), Cologne, Germany. www.aaai. org/ocs/index.php/ICWSM/ICWSM16/paper/ download/13020/12738

Kasmir. 2012. Manajemen Perbankan. Jakarta: PT RajaGrafindo Persada

Kerr SP, Kerr WR, Xu T. 2017. Personality Traits of Entrepreneurs: A Review of Recent Literature. https://www.hbs.edu/faculty/Publication $\% 20$ Files/18-047_b0074a64-5428-479b-8c8316f2a0e97eb6.pdf [17 June 2019].

Leutner F, Ahmetoglu G, Akhtar R, ChamorroPremuzic T. 2014. The relationship between the entrepreneurial personality and the big five personality traits. Personality and Individual Differences 63:58-63. http://dx.doi. org/10.1016/j.paid.2014.01.042

Lounsbury JW, Smith RM, Levy JJ, Leong FT \& Gibson LW. 2009. Personality characteristics of business majors as defined by the big five and narrow personality traits. Journal of Education for Business 84(4): 200-205. https://doi. org/10.3200/JOEB.84.4.200-205

McCrae RR, Costa PT. 1987. Validation of the fivefactor model of personality across instruments and observers. Journal of Personality and Social Psychology 52(1): 81-90. http://dx.doi. org/10.1037/0022-3514.52.1.81

McCrae RR, Costa PT. 1991. The NEO personality inventory: using the five-factor model in counseling. Journal of Counseling \& Development 69(4): 367-372. http://dx.doi. org/10.1002/j.1556-6676.1991.tb01524.x

Mostafa M, Crick T, Calderon AC, Oatley G. 2016. Incorporating Emotion and Personality-Based Analysis in User-Centered Modelling. In: Bramer 
M., Petridis M. (eds) Research and Development in Intelligent Systems XXXIII. SGAI 2016. Springer, Cham.

Na WB, Marshall R. 1999. Validation of the "big five" personality traits in Korea. Journal of International Consumer Marketing 12(1):5-19.

Norman WT. 1963. Toward an adequate taxonomy of personality attributes: replicated factor structure in peer nomination personality ratings. Journal of Abnormal and Social Psychology 66:573-583.

Obschonka M, Fish C, Boyd R. 2017. Using digital footprints in entrepreneurship research: A Twitter-based personality analysis of superstar entrepreneurs and managers. Journal of Business Venturing Insights 8: 13-23.

Pines AM, Lerner M, Schwartz D. 2010. Gender differences in entrepreneurship. Equality, Diversity and Inclusion: An International Journal 29(2): 186-198.

Rothmann S, Coetzer E. 2003. The big five personality dimensions and job performance. SA Journal of Industrial Psychology 29 (1):68-74.

Ryan T, Xenos S. 2011. Who uses Facebook? An investigation into the relationship between the big five, shyness, narcissism, loneliness, and facebook usage. Computers in Human Behavior 27(5): 1658-1664. https://doi.org/10.1016/j. chb.2011.02.004.
Schober P, Boer C, Schwarte LA. 2018. Correlation coefficients: appropriate use and interpretation. Anesthesia \& Analgesia 126(5): 1763-1768.

Shao AT. 2002. Marketing Research: An aid to Decision Making. 2nd Ed., Ohio: Thomson Learning.

Startup Ranking. 2019. Startup Ranking IndonesiaTop.http://www.startupranking.com/top/ indonesia [17 June 2019].

Thies F, Wessel M, Rudolph J, Benlian A. 2016. Personality Matters: How Signaling Personality Traits Can Influence the Adoption and Diffusion of Crowdfunding Campaigns. Paper presented at the 2016 European Conference on Information System. http://aisel.aisnet.org/ecis2016_rp/36

Tupes EC, Christal RE. 1961. Recurrent personality factors based on trait ratings (USAF ASD Technical Report No. 61-97). Lackland Air Force Base, Texas: US Air Force.

Widyasthana GNS, Wibisono D, Purwanegara MS, Siallagan M. 2017. Corporate Venture Capital Variable for Investing in Start-up in Indonesia. International Journal of Innovation and Research in Educational Sciences 4(3): 2349-5219.

Zhao H, Seibert SE. 2006. The big five personality dimensions and entrepreneurial status: A metaanalytical review. Journal of Applied Psychology 91: 259-271. 